$10-2017$

\title{
Book Review: From War to Genocide: Criminal Politics in Rwanda, 1990-1994
}

Erin Jessee

Scottish Oral History Centre, University of Strathclyde

Follow this and additional works at: https://digitalcommons.usf.edu/gsp

\section{Recommended Citation}

Jessee, Erin (2017) "Book Review: From War to Genocide: Criminal Politics in Rwanda, 1990-1994,"

Genocide Studies and Prevention: An International Journal: Vol. 11: Iss. 2: 116-117.

DOI:

http://doi.org/10.5038/1911-9933.11.2.1476

Available at: https://digitalcommons.usf.edu/gsp/vol11/iss2/14

This Book Review is brought to you for free and open access by the Open Access Journals at Digital Commons @ University of South Florida. It has been accepted for inclusion in Genocide Studies and Prevention: An International Journal by an authorized editor of Digital Commons @ University of South Florida. For more information, please contact digitalcommons@usf.edu. 
Book Review: From War to Genocide: Criminal Politics in Rwanda, 1990-1994

\author{
Erin Jessee \\ Scottish Oral History Centre, University of Strathclyde \\ Glasgow, Scotland
}

From War to Genocide: Criminal Politics in Rwanda, 1990-1994

André Guichaoua, translated by Don E. Webster

Madison, University of Wisconsin Press, 2015

416 Pages; Price: $\$ 79.95$ Paperback

Reviewed by Erin Jessee

Scottish Oral History Centre at the University of Strathclyde (UK)

André Guichaoua's From War to Genocide: Criminal Politics in Rwanda, 1990-1994 is an important addition to English-language scholarship on the 1994 genocide in Rwanda, during which an estimated 800,000 Rwandan civilians - most of whom were members of the nation's ethnic Tutsi minority - were murdered by Hutu Power extremists and their collaborators. Previously available only in French (2010) and now clearly rendered into English by Don Webster, the book draws upon an impressive range of evidence collected by the Office of the Prosecution for the International Criminal Tribunal for Rwanda (ICTR) as part of its efforts to hold accountable those individuals with primary criminal responsibility for the genocide. As the former lead expert witness for the prosecution at the ICTR, Guichaoua had unprecedented access to these materials, which he then supplemented with his own interviews and related fieldwork among Rwandans who had been close to Presidents Juvénal Habyarimana (r. 1973-1994) and Théodore Sindikubwabo (r. April-July 1994), the interim President who took power following Habyarimana's assassination. The outcome is a comprehensive overview of the civil war and genocide in Rwanda and one that speaks to several key points of controversy among experts on the conflict.

The book is organized chronologically according to thirteen phases in Rwanda's recent history. Chapter 1 offers a brief overview of the social and political context in Rwanda under the Habyarimana regime. Chapter 2 then shifts to Uganda to consider how the political climate in Rwanda under Habyarimana's leadership-dominated by Hutu from northern Rwanda-prompted a cohort of predominantly Tutsi Rwandan refugees based in Uganda to organize, militarize, and invade Rwanda in 1990, triggering a civil war and initiating a period of political transition detailed in Chapter 3. Chapter 4 subsequently explains how escalating political tensions and violence between Habyarimana's military and the invading Rwanda Patriotic Front (RPF) necessitated the Arusha Peace Process, overseen by the international community, and led to the Arusha Accords - the subject of Chapter 5-as a means of promoting a peaceful transition to a multi-party democratic state that would include representation by the RPF. In Chapter 6, however, Guichaoua outlines how the Arusha Accords ultimately prompted a growing cohort of Hutu Power extremists close to Habyarimana to begin organizing militia groups initially aimed at ensuring adequate civil defense mechanisms were in place to protect Rwandan communities from a potential RPF advance.

With Habyarimana's assassination on 6 April 1994-an act of aggression that Guichaoua argues in Chapter 7 was likely orchestrated by the leader of the RPF and current President of Rwanda, Paul Kagame - the gradual increase in anti-RPF sentiments among the general population and the infiltration of key Rwandan institutions by Hutu Power extremists set the stage for the extermination of the political opposition, but not necessarily targeted massacres of Tutsi civilians at this juncture. Of particular relevance for scholarship on the Rwandan genocide, the evidence outlined in Chapters 8, 9, and 10 suggests the genocide was not planned in advance by the interim government officials who took control following Habyarimana's death, as is commonly argued in the literature and in present-day Rwanda. Instead, Guichaoua finds the genocide emerged rather suddenly as part of a desperate attempt by the interim government to thwart an increasingly inevitable RPF military victory by inciting chaos among the civilian population, most notably after the interim government was forced to abandon the nation's capital, Kigali, to the RPF military 
advance, around 12 April 1994. After this date, interim government officials from their new seat near Gitarama in southern Rwanda began actively encouraging massacres of Tutsi civilians by militia groups, a shift in strategy that is outlined in Chapter 11 and which led to an escalation in specifically anti-Tutsi violence despite varied responses among the Hutu civilians who were expected to participate in this new 'civil defense' policy. Chapter 12 then focuses on the last days of the war between the disintegrating interim government and advancing RPF forces, and the accompanying genocide, with particular emphasis placed on understanding the legal consequences of particular interim government officials' decisions to incite genocide in a desperate attempt to advance their political ambitions.

In Chapter 13, Guichaoua turns his attention to how the eventual RPF military victory has led to a sustained effort among both extremist supporters of the interim government and the RPF to revise Rwanda's history in a manner that reinforces their political agendas in the present. Those extremists who would dismiss the 1994 genocide as an accident or the unfortunate side-effect of a civil war are rarely taken seriously beyond the more polarized members of Rwanda's political opposition in exile. The RPF has been largely successful in its efforts to demonize the Habyarimana regime and rewrite Rwanda's history such that the genocide can be understood as the inevitable outcome of decades of anti-Tutsi hatred that was manipulated by Hutu politicians to distract citizens from the corruption that plagued Rwanda during the First and Second Hutu Republics. The international community has been quick to adopt the RPF's version of events, as evidenced by the ICTR's decisions to only prosecute crimes committed from January to December 1994, and focus on prosecuting high-level officials within the interim government who were responsible for perpetrating war crimes, crimes against humanity, and genocide, while ignoring those RPF officials who allegedly also engaged in war crimes and crimes against humanity against Hutu civilians or who were arguably complicit in Habyarimana's assassination, for example. Guichaoua concludes his study by highlighting the resulting disconnect in Rwanda between "judicial truth" and the "researcher's truth" and calls upon future researchers to "rise to the intellectual challenge of closely examining the unfolding of the war and the inception of genocide" to reveal "the specificities of this major human tragedy, which was unexpected yet failed to surprise the majority of those involved." ${ }^{1}$

Taken together, From War to Genocide offers a thorough overview of the rapidly shifting political climate in Rwanda during the civil war and genocide grounded almost entirely in primary sources $^{2}$ and Guichaoua's extensive knowledge of Rwandan politics. Guichaoua painstakingly reconstructs a controversial period in Rwanda's history, highlighting along the way the actions of key government officials within the Habyarimana regime and subsequent interim government as they fought to maintain control of Rwanda amid civil war and genocide. To this end, Guichaoua strikes an effective balance between exploring the complex and increasingly desperate decisionmaking processes which following Habyarimana's death prompted the interim government to first seek vengeance against Rwanda's political opposition regardless of ethnicity, and subsequently incite genocide against Rwanda's minority Tutsi population, and nonetheless holding these officials accountable for their crimes. Nonetheless, it is likely to strike a negative chord with supporters of the Kagame regime who maintain that Kagame and the RPF was in no way responsible for assassinating Habyarimana, and that the genocide was the inevitable result of a long plan on the part of the Habyarimana regime and the interim government to exterminate Rwanda's Tutsi minority population. However, given the rigor that Guichaoua applies in analyzing the evidence that was collected by the Office of the Prosecutor for the ICTR and balancing it against the politics of memory and history that surround Rwanda's civil war and genocide, there is no doubt that for many scholars and experts on Rwanda his book will become the final word on the subject, at least until new sources of evidence are uncovered.

\footnotetext{
${ }^{1}$ André Guichaoua, From War to Genocide: Criminal Politics in Rwanda, 1990-1994, trans. Don E. Webster (Madison: University of Wisconsin Press, 2015), 336.

${ }^{2}$ Many of which are available online at the book's website, http://rwandadelaguerreaugenocide.univ-paris1.fr/home/.
} 